\title{
Effect of bending of shoots on flowering, yield and quality of guava cv. Khaja
}

\author{
P. Nandi*, D. Roy, B. Ghosh and S. Kundu \\ Department of Fruits and Orchard Management, Faculty of Horticulture, Bidhan Chandra Krishi Viswavidyalaya, \\ Mohanpur-741252, Nadia (West Bengal), INDIA \\ *Corresponding author. E-mail: paromitanandi20@gmail.com
}

Received: May 31, 2016; Revised received: February 20, 2017; Accepted: July 5, 2017

\begin{abstract}
The study of the effect of bending of shoots in different months in guava cv. Khaja was carried out at Horticulture Research Station, Mondouri of Bidhan Chandra Krishi Viswavidyalaya to find out suitable bending time for improving flowering, yield and quality of guava. The experiment consists of seven treatments with three replications in a randomised block design. The different treatments were bending in October $\left(T_{1}\right)$, November $\left(T_{2}\right)$, March $\left(T_{3}\right)$, April $\left(T_{4}\right)$, May $\left(T_{5}\right)$, June $\left(T_{6}\right)$ and untreated control $\left(T_{7}\right)$. Bending in June $\left(T_{6}\right)$ resulted early emergency of new shootlet (15.0 days), flower initiation (40.33 days) and fruit set (48.33 days) from the date of bending as well as the same treatment showed maximum fruit weight $(197.67 \mathrm{gm})$, fruit length $(8.00 \mathrm{~cm})$, fruit diameter $(7.16 \mathrm{~cm})$ and pulp thickness $(2.20 \mathrm{~cm})$. Higher fruit quality in terms of total soluble solids $\left(11.04{ }^{\circ} \mathrm{brix}\right)$, total sugar $(7.0 \%)$ and ascorbic acid content $\left(197.96 \mathrm{mg} / 100 \mathrm{~g}\right.$ pulp) was noted when bending was done in May $\left(\mathrm{T}_{5}\right)$ and June $\left(\mathrm{T}_{6}\right)$. Bending in the month of October $\left(T_{1}\right)$ resulted in maximum $\mathrm{C}$ : $\mathrm{N}$ ratio of leaf with maximum flowering shootlets in a branch and yield (63.67 kg/plant). So, time of bending may be standardized in the month of October or June for higher profit.
\end{abstract}

Keywords: Ascorbic acid, Bending time, Flowering shootlet, Fruit yield, Leaf C: N ratio

\section{INTRODUCTION}

Guava (Psidium guajava L.), an apple of tropics, is the fifth most important fruit of India both in area and production after banana, mango, apple and citrus. Because of its high nutritive value and medicinal value, regular bearing and wider adoptability under various agroclimatic conditions guava has become more popular in our country. The guava bears solitary or in cymes of 2 3 flower on the current reasons growth in the axils of four to five pairs of leaves. The well defined flowering periods in West Bengal condition are 'ambe bahar' and 'mrig bahar'. Ambe bahar flowers during February March and ripens during rainy season. But rainy season's fruits are insipid, watery and poor in taste with poor keeping quality and are generally infested with pests and diseases. On the other hand, mrig bahar flowers during June - July and ripens during winter. Fruits of mrig bahar are excellent in quality with high TSS, acidity, ascorbic acid and low water content. Unfortunately, guava bears mainly in rainy season and in lesser amount in winter season in West Bengal with little or no fruiting in the spring - summer season. Farmers get minimum price because markets are flooded with guava fruits during rainy season. Bending shoots of guava, an indigenous technical knowledge, is practised commercially in few pockets of West Bengal for regulation of flowering in the off season (autumn to early summer). This technology is supported by National agricultural technology project (NATP) and is remunerative and cost effective.

Bending induces profuse flowering and fruiting and fetches greater returns (Ghosh and Sukul 2003; Sarkar et al., 2005). Shoot bending also improved productivity of guava in different varieties at Bangladesh (Mamun et al., 2012). This technology expects to improve the livelihood security of rural people and farmers. But the response of bending in different months has not been performed yet. Again, among different varieties, the variety 'Khaja' is growing commercially in West Bengal due to its attractiveness and consumers preference.

Therefore, it was desirable to regulate guava (Psidium guajava L.) crop in such a way that higher yield with better quality fruits are obtained during winter and spring season by eliminating poor quality rainy season crop. So, the present experiment was therefore undertaken to find out the suitable bending time for improving flowering, yield and quality.

\section{MATERIALS AND METHODS}

The present investigation was undertaken in guava (Psidium guajava L.) cv. Khaja during the year 201214 at Horticultural Research Station, Mondouri, Bidhan Chandra Krishi Viswavidyalaya which is situated between $22.43{ }^{0} \mathrm{~N}$ latitude and $88.34{ }^{0} \mathrm{E}$ longitude with an altitude of $9.75 \mathrm{~m}$ above the mean sea level. The experiment was laid out in randomized block design with seven treatments of bending in different months as October $\left(\mathrm{T}_{1}\right)$, November $\left(\mathrm{T}_{2}\right)$, March $\left(\mathrm{T}_{3}\right)$, April 
$\left(\mathrm{T}_{4}\right)$, May $\left(\mathrm{T}_{5}\right)$, June $\left(\mathrm{T}_{6}\right)$ and untreated control $\left(\mathrm{T}_{7}\right)$. Each treatment was replicated thrice with single plant in each replication. The plants were four years old with a spacing of $6 \mathrm{~m} \times 6 \mathrm{~m}$. Before bending some of the shoots were thinned off and rest of the shoots was cleaned from the base of the shoot except $25-30 \mathrm{~cm}$ of terminal portion. Then all the branches of plant were bent down and tied to the base of the plant by coconut thread. Planofix @1ml/1 of water was applied immediately after bending. Fertilizer@450 g N, 300 g $\mathrm{P}_{2} \mathrm{O}_{5}$ and $450 \mathrm{~g} \mathrm{~K}_{2} \mathrm{O}$ were applied per plant in two equal split doses viz, 15 days before bending and at marble stage of fruit growth.

Observations were recorded with respect to number of new shootlets / branch, days required for emergence of new shoot, flower initiation and fruit set, number of flowering shootlets / branch, number of flowers / shootlet, number of fruits / branch at fruit set stage, fruit yield, fruit weight, fruit length, fruit diameter, pulp thickness and quality of fruit (TSS, total sugar, reducing sugar, total titratable acidity, ascorbic acid). Total carbohydrate and nitrogen content of leaves were also analyzed.

Recently matured $3^{\text {rd }}$ and $4^{\text {th }}$ leaves from growing tip were sampled after fruit set for estimation of total carbohydrate and nitrogen. Collected leaf samples were washed with distilled water to make them dust free and then dried and placed in hot air oven in a brown paper bag at $68{ }^{\circ} \mathrm{C} \pm 2$ for 72 hours. The dried samples were grinded and collected in brown paper for analysis of total carbohydrate (Hedge and Hofreiter 1962) and nitrogen (Black, 1965). The physical and chemical characters of fruits were recorded after thorough washing with tap water to remove adhering impurities. Fruit weight was measured by using electronic (digital) balance whereas pulp thickness was measured by scale. TSS content of fruits was determined with the help of a hand refractometer. The sugars, acidity and ascorbic acid content of fruit were estimated by following the standard methods (A. O. A. C., 1984). The data obtained were analyzed statistically by the analysis of variance method as suggested by Goon et al. (2001) and the significance of different source of variation was tested by error mean square by Fisher's ' $F$ ' test of probability level of 0.05 per cent.

\section{RESULTS AND DISCUSSION}

The present study revealed from the data presented in table 1 that bending in summer months (March to June) resulted early emergence of new shoot (15.0 to 19.3 days) as well as early flowering (40.3 - 50.7 days) and fruit set (48.3 - 58.3 days) as compared to may and bending done in autumn months (October and November). Among summer months, it was earlier more when bending was done in May and June. Ghosh and Sukul (2003) also reported that summer season bending is more responsive in early emergence of new shootlets in profuse number.

Table 1. Effect of bending of shoots on new shoot production of guava.*

\begin{tabular}{|c|c|c|c|c|c|}
\hline Treatment & $\begin{array}{lr}\text { Days } & \text { required } \\
\text { emerge } & \text { new shoot }\end{array}$ & to & $\begin{array}{l}\text { Number of new } \\
\text { shootlet per branch }\end{array}$ & $\begin{array}{l}\text { Days required to } \\
\text { initiate flowers }\end{array}$ & $\begin{array}{l}\text { Days required for } \\
\text { fruit set }\end{array}$ \\
\hline $\mathrm{T}_{1}$ & 23.67 & & 44.33 & 53.67 & 67.33 \\
\hline $\mathrm{T}_{2}$ & 27.33 & & 41.67 & 65.33 & 78.00 \\
\hline $\mathrm{T}_{3}$ & 19.33 & & 32.00 & 50.67 & 58.34 \\
\hline $\mathrm{T}_{4}$ & 18.00 & & 26.33 & 45.00 & 55.00 \\
\hline $\mathrm{T}_{5}$ & 17.33 & & 23.67 & 43.43 & 50.35 \\
\hline $\mathrm{T}_{6}$ & 15.00 & & 24.00 & 40.33 & 48.33 \\
\hline $\mathrm{T}_{7}$ & 46.16 & & 13.67 & 42.67 & 68.00 \\
\hline $\mathrm{S} . \mathrm{E}(\mathrm{m}) \pm$ & 3.655 & & 3.256 & 2.940 & 3.100 \\
\hline C.D.at $5 \% 1$ & 11.194 & & 16.406 & - & كـ \\
\hline
\end{tabular}

$\mathrm{T}_{1}$ - Bending in October, $\mathrm{T}_{2}$ - Bending in November, $\mathrm{T}_{3}$ - Bending in March, $\mathrm{T}_{4}-$ Bending in April, $\mathrm{T}_{5}-$ Bending in May, $\mathrm{T}_{6}-$

Table 2. Effect of bending of shoots on flowering, fruit set and yields of guava.*

\begin{tabular}{lllll}
\hline Treatments & $\begin{array}{l}\text { Number of flowering } \\
\text { shoot lets / branch }\end{array}$ & $\begin{array}{l}\text { Number of flower / } \\
\text { shoot let }\end{array}$ & $\begin{array}{l}\text { Number of fruits/ } \\
\text { branch at fruit set stage }\end{array}$ & $\begin{array}{l}\text { Number of fruits/ } \\
\text { plant at harvest }\end{array}$ \\
\hline $\mathrm{T}_{1}$ & 32.33 & 6.33 & 60.68 & 384.64 \\
$\mathrm{~T}_{2}$ & 25.00 & 5.00 & 16.33 & 259.34 \\
$\mathrm{~T}_{3}$ & 23.66 & 3.00 & 26.67 & 241.36 \\
$\mathrm{~T}_{4}$ & 27.33 & 3.66 & 10.00 & 247.34 \\
$\mathrm{~T}_{5}$ & 15.66 & 5.66 & 24.00 & 258.00 \\
$\mathrm{~T}_{6}$ & 22.00 & 6.00 & 28.33 & 285.00 \\
$\mathrm{~T}_{7}$ & 7.33 & 1.67 & 8.66 & 194.66 \\
$\mathrm{~S} . \mathrm{E}(\mathrm{m}) \pm$ & 2.466 & 0.701 & 3.271 & 25.796 \\
C... & 7.551 & 2.148 & 10.017 & 79.002
\end{tabular}

$\mathrm{T}_{1}$ - Bending in October, $\mathrm{T}_{2}$ - Bending in November, $\mathrm{T}_{3}$ - Bending in March, $\mathrm{T}_{4}-$ Bending in April, $\mathrm{T}_{5}-$ Bending in May, $\mathrm{T}_{6}-$ 
P. Nandi et al. / J. Appl. \& Nat. Sci. 9 (3): 1365 - 1368 (2017)

Table 3. Total Carbohydrate and nitrogen content of leaf due to bending of shoots.*

\begin{tabular}{llll}
\hline Treatments & Nitrogen (\%) & Carbohydrate (\%) & C:N ratio \\
\hline $\mathrm{T}_{1}$ & 2.90 & 10.46 & 3.61 \\
$\mathrm{~T}_{2}$ & 2.85 & 8.65 & 3.03 \\
$\mathrm{~T}_{3}$ & 2.76 & 8.67 & 3.14 \\
$\mathrm{~T}_{4}$ & 2.78 & 8.85 & 3.18 \\
$\mathrm{~T}_{5}$ & 2.77 & 9.48 & 3.42 \\
$\mathrm{~T}_{6}$ & 2.92 & 9.70 & 3.32 \\
$\mathrm{~T}_{7}$ & 2.65 & 6.86 & 2.59 \\
\hline
\end{tabular}

$\mathrm{T}_{1}$ - Bending in October, $\mathrm{T}_{2}$ - Bending in November, $\mathrm{T}_{3}$ - Bending in March, $\mathrm{T}_{4}$ - Bending in April, $\mathrm{T}_{5}-$ Bending in May, $\mathrm{T}_{6}$ Bending in June, $\mathrm{T}_{7}$ - Control. ${ }^{*}$ Values are means of 30 observations (10/replication)

Table 4. Effect of bending of shoots on yield and yield attributing characters of guava.*

\begin{tabular}{|c|c|c|c|c|c|}
\hline Treatments & $\begin{array}{l}\text { Fruit weight } \\
\text { (g) }\end{array}$ & $\begin{array}{ll}\begin{array}{l}\text { Fruit } \\
\text { (cm) }\end{array} & \text { length } \\
\end{array}$ & $\begin{array}{ll}\begin{array}{l}\text { Fruit } \\
\text { (cm) }\end{array} & \text { diameter } \\
\end{array}$ & Pulp thickness (cm) & Yield (kg/plant) \\
\hline $\mathrm{T}_{1}$ & 165.53 & 5.57 & 5.2 & 1.27 & 63.67 \\
\hline $\mathrm{T}_{2}$ & 160.30 & 5.20 & 4.97 & 1.16 & 41.57 \\
\hline $\mathrm{T}_{3}$ & 150.27 & 5.53 & 5.40 & 1.23 & 36.26 \\
\hline $\mathrm{T}_{4}$ & 170.20 & 6.44 & 6.57 & 2.00 & 42.09 \\
\hline $\mathrm{T}_{5}$ & 185.37 & 7.02 & 6.82 & 1.58 & 47.94 \\
\hline $\mathrm{T}_{6}$ & 197.67 & 8.00 & 7.16 & 2.20 & 56.33 \\
\hline $\mathrm{T}_{7}$ & 160.73 & 5.86 & 5.27 & 0.93 & 31.28 \\
\hline $\mathrm{SE}(\mathrm{m}) \pm$ & 14.75 & 0.141 & 0.427 & 0.128 & 5.751 \\
\hline C.D. at $5 \%$ level & $\mathrm{NS} * *$ & 0.43 & 0.140 & 0.393 & 17.612 \\
\hline
\end{tabular}

NS** $=$ Non Significant; $\mathrm{T}_{1}$ - Bending in October, $\mathrm{T}_{2}$ - Bending in November, $\mathrm{T}_{3}$ - Bending in March, $\mathrm{T}_{4}-$ Bending in April, $\mathrm{T}_{5}$ Bending in May, $\mathrm{T}_{6}$ - Bending in June, $\mathrm{T}_{7}$ - Control.*Values are means of 30 observations (10/replication)

Table 5. Effect of bending of shoots on fruit quality of guava.*

\begin{tabular}{llllll}
\hline Treatments & TSS ( ${ }^{\mathbf{0}}$ Brix) & $\begin{array}{l}\text { Total Sugar } \\
\text { (\%fresh weight) }\end{array}$ & $\begin{array}{l}\text { Reducing Sugar } \\
\text { (\%)fresh weight) }\end{array}$ & $\begin{array}{l}\text { Ascorbic } \\
\text { Acid content } \\
\text { (mg/100g of pulp) }\end{array}$ & $\begin{array}{l}\text { Titratable } \\
\text { Acidity } \\
\text { weight) }\end{array}$ \\
\hline $\mathrm{T}_{1}$ & & 5.6 & 4.73 & 98.84 & 0.49 \\
$\mathrm{~T}_{2}$ & 9.50 & 5.0 & 4.21 & 133.85 & 1.31 \\
$\mathrm{~T}_{3}$ & 9.00 & 6.0 & 4.73 & 175.70 & 0.92 \\
$\mathrm{~T}_{4}$ & 9.60 & 6.6 & 5.10 & 175.55 & 0.62 \\
$\mathrm{~T}_{5}$ & 10.50 & 5.23 & 197.96 & 1.41 \\
$\mathrm{~T}_{6}$ & 11.04 & 6.0 & 4.56 & 195.55 & 0.44 \\
$\mathrm{~T}_{7}$ & 10.19 & 4.5 & 3.90 & 132.96 & 0.29 \\
SE(m) \pm & 0.51 & 0.645 & 0.171 & 2.169 & 0.038 \\
C.D. at 5\% level & 0.183 & NS** & 0.523 & 8.020 & 0.116 \\
\hline
\end{tabular}

NS** = Non Significant; $\mathrm{T}_{1}$ - Bending in October, $\mathrm{T}_{2}$ - Bending in November, $\mathrm{T}_{3}$ - Bending in March, $\mathrm{T}_{4}-$ Bending in April, $\mathrm{T}_{5}$ Bending in May, $\mathrm{T}_{6}$ - Bending in June, $\mathrm{T}_{7}$ - Control. *Values are means of 30 observations (10/replication)

The number of flowering shootlets, number of flowers, fruit set and number of fruit at harvest significantly varied at $5 \%$ level among different treatments with much higher number with bending treatments as compared to control (Table 2). Bagchi et al. (2008) opined that the main physiology of increased flowering and fruiting by bending treatment might be due to higher $\mathrm{C}$ : $\mathrm{N}$ ratio. According to them, tryptophan accumulation in the leaves was increased due to bending. Beside higher lipid in the bark at the initial stage and in leaves at later stage signified the tendency of plant to overcome shock effect of bending and pruning. Wang et al. (2010) also revealed that bending of shoot in apple increased flowering by altering hormonal balance in shoot and specially the level of endogenous Abscisic acid (ABA) content in shoot tip as well as in the fine roots was positively correlated with branch bending and was significantly higher than that of control. The data presented in the Table 3 also showed higher $\mathrm{C}: \mathrm{N}$ ratio (3.03 - 3.61) with different bending treatments as compared to control (2.59). It is clear from Table 2 and 3 that bending in the month of October $\left(T_{1}\right)$ resulted maximum number of flowering shoot lets (32.33) and fruit set/branch (60.68), flowers/shoot let (6.33), fruits/ plant (384.64) and $\mathrm{C}: \mathrm{N}$ ratio of leaf (3.01). The earlier finding of Ghosh and Sukul (2003) also suggested that autumn season bending produces more reproductive shoots per branch with maximum production. Mamun et al. (2012) also stated that bending improves the physiology of the plant. He stated that the highest 
number of flowers set per plant was recorded in the shoot bending treatment during on-season (312.33) and off-season it was (111.33). The shoot bending treatment resulted in the highest number of fruits set per plant both on and off season (246.86) and (67.33) respectively.

Yield, yield attributing characters and fruit quality varied widely in bending treatments (Table 4 and 5). Bending in the month of May $\left(\mathrm{T}_{5}\right)$ and June $\left(\mathrm{T}_{6}\right)$ showed higher fruit weight, fruit size (length and diameter) and pulp thickness compared to remaining treatments. In spite of higher yield attributing characters due to bending in May $\left(T_{5}\right)$ and June $\left(T_{6}\right)$, maximum yield (kg/plant) was recorded by bending in October $\left(T_{1}\right)$. The maximum fruit yield $(63.67 \mathrm{~kg} / \mathrm{plant})$ by bending in October $\left(T_{1}\right)$ was due to higher number of reproductive shoot lets/ branch (32.33) and higher number of fruits /plant (384.64). This explanation of higher fruit yield during bending in autumn season (October) is in support of earlier findings of Ghosh and Sukul (2003). The fruit yield was moderate when bending was done in May (47.94 kg/plant) and June (56.33 kg/plant). During off-season, the highest fruit yield $(13.50 \mathrm{~kg} /$ plant $)$ was recorded in shoot bending treatment, also stated by Mamun et al. (2012). Bending in the month of May resulted quality fruits in terms of TSS $\left(11.04^{0}\right.$ brix), total sugar $(7.0 \%)$, reducing sugar (5.23\%), ascorbic acid (197.96 mg/100 gm of pulp). However, bending in the month of June also resulted higher ascorbic acid content $(195.55 \mathrm{mg} / 100 \mathrm{gm}$ of pulp) and lesser acidity (0.44\%) in fruits. Samant et al. (2016) also support the statement that bending gave better quality guava fruit with highest TSS $\left(10.18^{0}\right.$ brix) and ascorbic acid content (204.60 mg/100g pulp).

\section{Conclusion}

It was concluded that bending in the month of October is most effective in increasing flowering shoot (32.33/ branch) and fruit yield (63.66 kg/plant) followed by bending in June. Therefore, the time of bending may be standardized in the month of October or June for higher profit from spring-summer or winter crop respectively.

\section{REFERENCES}

A. O. A. C. 1984. Official Methods of Analysis, $14^{\text {th }}$ Ed. Association of Official Agricultural Chemist, Washington D. C., 16.

Bagchi, T. B., Sukul, P. and Ghosh, B. (2008). Biochemical changes during off-season flowering in guava (Psidium guajava L.) induced by bending and pruning. J. Tropic. Agric., 46 (1/2): 64-66.

Black, C. A. (1965). Method of Soil Analysis. American Soc. Agron. Inc., Madison, 75-1171.

Ghosh, B. and Sukul, P. (2003). Off season flowering in guava. In: Validation of Indigenous Technical Knowledge in Agriculture, Document-3. Mission Unit, Division of Agricultural Extension. ICAR, New Delhi, 220-226.

Goon, A. M., Gupta, M. K. and Dasgupta, B. (2001). Fundamentals of Statistics, Vol. 2, The World Press Limited, Calcutta, $72-76$.

Hedge, J. E. and Hofreiter, B. T. (1962). In: Carbohydrate Chemistry (Eds. Whistler R.L. and Be Miller, J.N.), Academic Press, New York, 17.

Mamun, A. A., Rahman, M. H. and Rahim, M. A. (2012). Effect of shoot Beding and Fruit Thinning on Productivity of Guava. J. Environ. Sci. \& Natural Resources, 5 (2): 167-172.

Samant, D., Kishore, K. and Singh, H. S. (2016). Branch Bending for Crop Regulation in Guava under Hot and Humid Climate of Eastern India. J. Indian Soc. Coastal agric. Res. 34(1): 92-96.

Sarkar, A., Ghosh, B., Kundu, S. and Sukul, P. (2005) Effect of shoot pruning and bending on yield and fruit quality in guava cv. L-49. Environ. \& Eco., 235:621-23.

Wang, L., Jiang, Y. M., Peng, F. T. and Wei, S. C. (2010). Effects of branch bending on growth of new shoots and the dynamic changes of endogenous hormones in apple. Scientia Agricultura Sinica, 43 (22): 4761-4764. 